\title{
The Parallels between Kantian Aesthetics and the Presence of Tibetan Art in the Yuan-Ming Era (1279-1644)
}

\author{
Andrei-Valentin Bacrău ${ }^{1,2}$ \\ Received: 27 February 2021 / Accepted: 17 June 2021 / \\ Published online: 5 September 2021 \\ (c) The Author(s) 2021
}

\begin{abstract}
This paper will look at Kant's views of the aesthetic experience, in relationship to Buddhist philosophical and political discussions of art and social organization. The primary focus in Kantian literature explores the relationship between free and dependent beauty, as well as Kant's paradox of taste. The central argument of the Kantian portion is going to navigate the paradox of taste via Graham Priest's epistemic and conceptual distinction pertaining to the limits of thought. Secondly, I shall contextualize the debate with similar argumentation found in medieval Tibetan literature, by thinkers such as Tsongkhapa and Drakpa Gyaltsen. Lastly, I shall look at the political and artistic state of affairs in Yuan and Ming Dynasties and assert the applicability of both Kantian and Tibetan discussions of effibility in the context of Tibetan poetry and Thangkas.
\end{abstract}

Keywords Kant $\cdot$ Aesthetics $\cdot$ Paradox of taste $\cdot$ Madhyamika philosophy $\cdot$ Two truth debate $\cdot$ Historical legacy $\cdot$ Yuan-Ming rule

\section{Kantian Transcendental Aesthetic}

The Kantian notion of transcendental aesthetics is interwoven with our ability as subjects to evaluate the external and internal world in such a way that we also discover, or rather recognize, an external natural order and harmony which gives rise to a normative urge to behave ethically according to universal standards. The overall Kantian argumentation of transcendentalism can sometimes become ambiguous due to his extensive usage of a priori causal notions. Therefore, it is important to clarify which claims Kant would think fall under the descriptive language of empirical discoveries. To Kant, all possible empirical knowledge, which is a posteriori, is

Andrei-Valentin Bacrău

bacrauandrew@gmail.com

1 University of Zürich, Zürich, Switzerland

2 Buddhist Studies, Nālandā University, Rajgir, India 
causally preceded by intuitions of space and time, intuitions which are both transcendental to the verificationist process of science, as well as our linguistic ability to describe the external world. Our subjective cognitive activity is mediated by our cognition of space and time, which directly interacts with our sensorial experience.

The difficulty in providing a complete and clear explanation of the Kantian transcendental aesthetic is because arguments have been put forward that Kant does change his position regarding the relationship between our senses and space-time cognitive activities (Falkenstein, 2004). However, there is one component that remains fairly consistent through Kant's views pertaining to the relationship of our subjective experience and its capacity to interpret reality. Namely, our subjective cognitive architectonic dynamically engages with criteria of reflection via cognitive mechanisms and activities, as well as the universalist component which mediates and recognizes the harmony of interdependence between nature itself and our subjective capacity to understand nature, as the thing in itself (Beck, 1998). This mediation behaves as a cognitive apparatus that, in the context of the aesthetic experience, results in experiences of pleasure containing some sort of normative element. This causal process is arguably consistent since Kant maintains the same stance pertaining to the object of mediation between the sensibilia and the natural order of the world, within the scope of both natural and transcendental laws.

The concept of aesthetic experience for Kant encompasses more than spatiotemporal transcendence of some sort. The aesthetic view also includes a dynamic experience of the senses, in relation to feelings of beauty encapsulated in pleasure, which is of two types: interested and disinterested. This particular component of Kant's aesthetics will later on be emphasized to bridge the similarities towards politics and art in medieval Asia. To extend the parallel between Kant's aesthetic paradigm and historical events of medieval Asia, I shall also work under the presumption that ethical claims are completely interdependent with political ones. Ethical statements entail political actions, as well as vice-versa. This symmetrical relationship between ethical and political reasoning are both imported not only from Kant's view of aesthetics, but also a strikingly similar approach Buddhist philosophy has towards the relationship between aesthetic and ethical experiences.

Davies (2012) differentiates the two types of beauty in Kant by the criteria of intrinsic functional mechanisms. Dependent beauty is illustrated as an experience emerging from a human-made creation, whereas free beauty is a perception towards nature that endows the experiencer with an a priori disposition towards the morally good (KU, 5:301) (Kant, 2000). To Kant, this inherent natural beauty is recognized conditionally. The subject must be predisposed to moral thinking in order for her faculty of reason to be able to generate the right cognitive associations such that beauty is recognized in nature. An argument could be made that this recognition of beauty behaves as a mechanism of enhancing the subject's capacity to apply moral reasoning. There are several exegetical dimensions that would both favor and disfavor such an interpretation of natural beauty. Allison (1966) emphasizes a passage from the Critique of Judgment $(K U)$ in which Kant seemingly is making a distinction between freedom of choice derived from natural beauty, and the imposition of moral duties upon our interaction with the natural world: 
$\mathrm{KU}(5: 210)^{1}$ :

For where the morallaw speaks there is, objectively, no longer any free choice with regard to what is to be done; and to show taste in one's conduct (or in judging that of others) is something very different from expressing one's moralmode of thinking; for the latter contains a command and produces a need, while modishtaste by contrast only plays with the objects of satisfaction without attaching itself to any of them. [my italics]

As a response, I would like to defer to a passage where Kant makes clearer the relationship between theoretical and practical reasons (KU 20:198). ${ }^{2}$ Indeed, Kant does stress the distinction that the principles of natural laws differ from the ones derived from principles of freedom. At the same time, Kant emphasizes aunity between these principles, since both theoretical and practical reasons derive their representational content in reference to the object of a proposition from "the nature of things". An object is represented in reality itself by a derivation of content undergone by practical reasons from theoretical ones. Therefore, although there are different practical constraints towards the application of theoretical and practical reasons, these concepts are nonetheless imported from the same source of theoretical reasons. I am hesitant to extrapolate additionally from KU 20:198 on the relationship between the unitary source of theoretical and practical reasons. There is a risk of overinterpretation. Kant himself seems concerned with a similar observation. In KU 20:230, Kant particularly emphasizes that any cognitive import of understanding pleasure and displeasure via a conceptual apparatus does not lead to a correct understanding of a particular feeling. ${ }^{3}$

Despite these conceptual, sensorial, and emotional entanglements, Kant did attempt to at least partially navigate the paradoxes. In $5: 198,{ }^{4}$ he provided a chart pertaining to the relationship between cognitive and conceptual faculties in such a way that it shows potential for some minimal resolution. Our faculty of reason is interwoven with the a priori principle of lawfulness, particularly in application to nature. Feelings of pleasure and displeasure are mediated by the faculty of judgment, via the principle of purposiveness, in application to art. Lastly, our faculty of desire is linked to reason, via the principle of a final end (empirically assessable causal maxim), which is applied to freedom. This dynamic and inevitable interdependence of aesthetic, moral and political concepts is salient for how Kant himself also indirectly links, or so I would argue, his regimentation of cognitive faculties to a sense of agency in the political space of a particular civilization.

However, Kant also recognizes that even these mediating notions may not fully illustrate the relationship between taste and aesthetic experiences on one hand, or aesthetic judgments on the other. These deontic and modal tensions pertaining to conceivability, possibility and obligations exemplified by the unity yet

\footnotetext{
1 Ibid. Guyer and Wood, pp. 96.

2 Ibid. Guyer and Wood, pp. 5.

3 Ibid. Guyer and Wood, pp. 31.

4 Ibid. Guyer and Wood, pp. 83.
} 
distinctiveness of theoretical and practical reasons is further synthesized by Kant's dialectic of taste, found in KU 5:339 ${ }^{5}$ :

1. Thesis. The judgment of taste is notbased on concepts, for otherwise it would be possible to dispute about it (decide by means of proofs).

2. Antithesis.The judgment of taste is based on concepts, for otherwise, despite its variety, it would not even be possible to argue about it (to lay claim to the necessary assent of others to this judgment).

There is no possibility of lifting the conflict between these two principlesunderlying every judgment of taste (which are nothing other than the two peculiarities of the judgment of taste represented above in the Analytic), except by showing that the concept to which the object is related in this sort of judgment is not taken in the same sense in the two maxims of the aesthetic power of judgment, that this twofold sense or point of view in judgingis necessary in our transcendental power of judgment, but also that the semblanceinvolved in the confusion of the one with the other is, as a natural illusion, unavoidable. [my italics]

Clearly, there is no reasonable way of squaring the circle here. Through the KU, Kant does not defer to some sort of conceptual transcendence in order to resolve the paradox either. Priest's attempt towards resolving the tension, however minimal, is worthy of mention. His contextualization of the logical tension in the context of Kant's phenomena/noumenal distinction provides some clarity towards how perhaps Kant engaged with another meaningful dimension of his Critiques, particularly the differentiation between epistemic and conceptual access. To Priest, the impossibility of knowledge in these discussions is not an epistemic barrier, but a conceptual one. Our thoughts themselves cannot formulate and contextualize the necessary syllogism to find a clear resolution (Priest, 1995).

On one hand, Kant explores the dialectic of the aesthetic via the distinction of free and dependent beauty. In order to understand what kind of implications does Priest's conceptual/epistemic distinction has to the aesthetic experience altogether, it necessitates an application to the discussion of free and dependent beauties. Burgess argues that the production of the aesthetic idea "instigates" the free play of imagination and understanding, meaning that the process of cognizing the aesthetic idea is a second-order cognitive process relative to the first order apprehension and unification of perception (Burgess, 1989). The argument continues that Kant's view of concepts necessitates a rule-governed procedure for the recognition of the object. These concepts are cognitively restricted by the identification process of a causal end. Additionally, the formal epistemic condition for determining the content of the concept is dependent alongside the identification of the (causal) finality. The process of identifying the finality is a result of recognizing the relationship

\footnotetext{
$\overline{5}$ Ibid. Guyer and Wood, pp. 215.
} 
between the free play of the senses and the aesthetic pleasure. This formulation by Burgess leads him with the following conclusive remarks. Firstly, the aesthetic idea is not real, or at least, never "realized in reality". 6 The satisfaction condition for the conceptual content of the aesthetic are the alignment of a multiplicity of equally plausible and reasonable explanations for both the identification of a finality, as well as an interpretation of the disinterested pleasure in and of itself. Burgess is quite content with this cognitive mediation of some sort of epistemic pluralism. The recognition of the object as beautiful is the end-in-itself, without any regard for additional conditions for conceivability or realizability. It is actually the mind itself that is intrigued by the form of finality, yet multiplicity of rationalizations and explanations for the experience of free beauty. Burgess' interpretation is skillful in developing a descriptive account of the interdependence of the free play of the senses in relation to the aesthetic experience as well as some sort of causal unity of apprehension and assertible maxims. However, there is still the question of a notional applicability towards dependent beauty and the salience of the normative component in the aesthetic.

Although I do not disagree with Burgess' reconstruction of Kant's aesthetic, there is a clarificatory remark that I would like to emphasize. This slight disagreement does not pertain with the conceptual formation of disinterested pleasure, but rather to the cognitive mediation undergone by the subject to arrive at the proposed formulation of disinterestedness via the aesthetic. The limits of conceivability and determination of concepts as functional towards a natural order are incomplete by merely deferring to the harmony of the free play of the senses. As earlier emphasized by evoking KU 5:301, Kant sees any sort of rationalization and by extension interest of the aesthetic via the prism of the interest in the moral and the good. The epistemic grounding for any cognitive or purely conceptual emergence or possibility of the aesthetic ontologically necessitates ${ }^{7}$ some sort of predisposition towards moral thinking, such that whatever beauty and/or order we see in nature itself, is an epistemic import from the lawfulness of practical reasoning. Therefore, my attempt is to provide a complementary explanation to Burgess, in the sense of broadening the analytic framework of the aesthetic, in order to encompass the normative component. The mediating notion that could further illustrate and extrapolate this relationship between the aesthetic and the normative is the one of purposiveness. Although Burgess himself might have indirectly used purposiveness under some broader synonymity with the concept of reflective judgment, there still needs to be some clarification for the normative implications of the aesthetic.

Firstly, the notion of purposiveness has representational content. KU 20:202 goes as follows:

\footnotetext{
6 Ibid. Burgess pp. 489.

7 This ontological necessity does not necessarily have to be causally antecedent to the moral in terms of actually experiencing the aesthetic itself. Burges himself mentions some causal unity between reflective judgment and disinterested pleasure. Therefore, my further formulation of the aesthetic as well as a reconstruction of Burges would hopefully be understood as complimentary interpretations; see KU $20: 221$.
} 
Thus if there is to be a concept or a rule which arises originally from the power of judgment, it would have to be a concept of things in nature insofar as nature conforms to our power of judgment, and thus a concept of a property of nature such that one cannot form any concept of it except that its arrangement conforms to our faculty for subsuming the particular given laws under more general ones even though these are not given;in other words, it would have to be the concept of a purposiveness of nature in behalf of our faculty for cognizing it, insofar as for this it is required that we be able to judgethe particular as contained under the general and subsumeit under the concept of a nature. [my italics]

This passage is particularly interesting because it shows a binding relationship between purposiveness and rules. Burgess correctly points out that recognition of objects is a rule-based procedure. However, the minimal mention of purposiveness under the guise of reflective judgment(s) necessitates the following clarifications:

1. Purposiveness is the regularity that binds cognitive activities to rules of mediation that lead to conceptualization.

2. This regularity manifolds as an object of perception for cognitive mediation between free and dependent beauty.

3. Purposiveness understood as a concept rather than a feeling, leads to formal ground towards the unity of apprehension.

Even with this three-step assessment, the paradox of taste seems to remain unresolved. Kant's solution to derivations of feelings from concepts does necessitate further attention, although the solution can only result in partial solvency. In KU 5:400-401, Kant states that these observable states of nature can only be described a finality if and only if we observe natural ends as intentional. ${ }^{8}$ The problem with this is that external objects do not have such intentional properties, hence the ascription of purposiveness in itself is completely dependent on the subjective observer. Conclusively, Kant states that we cannot make any objective affirmation or negation towards the external state of affairs without deferring to some sort of intelligence, either ours as humans or God's. Inevitably, we are left with the question of the relation and unity of theoretical and practical reasons because of the paradox of taste. There may be a reconciliation between Priests' epistemic/conceptual distinction, as well as Burgess' formal conditions for pluralism. The two-step solution provided by Burgess illustrates firstly the unity of perception and apprehension, and secondly the reconstruction of the object and the cognitive activity responsible for judgments. Similarly, Kant states in KU 5:220 $0^{9}$ that a conceptual ascription towards desires assumes a causal determination, although purposiveness can exist without an end in so far as we do not ascribe a causal relation to its intuitive and conceptual form, but rather derive its form and content from the will, which in turn can

\footnotetext{
8 Ibid. Guyer and Wood, pp. 270-1.

9 Ibid. Guyer and Wood, pp. 105.
} 
only asses practical circumstances. Therefore, the notion of purposiveness can be understood as some dispositional unrealizable concept that transcends the bounds of practical assertability in the context of theoretical interactions of the free play of the senses, but it can also have morphological implications for practical reasons in the context of identifying a finality. As Priest put it, in the experiences, however subtle of free beauty, we lack both formal conceptual and epistemic access into ascribing some sort of concept towards disinterestedness as a feeling, although purposiveness remains as a necessary constant for the cognitive mediation. Secondly, in the likes of relating a feeling of respect to a priori moral judgments (KU 20:230), there is an asymmetrical tension of ascribing concepts of duties to emotive dispositions to behave in a moral way. These implications are not only important towards how we understand Kant's architecture of beauty and the aesthetic, but also towards the describable parallels towards Buddhist discussions of effibility, enlightenment and ethical maxims.

\section{Tibetan Art and Prāsañgika Mādhyamika}

The debates of conceptual and epistemic access are in no way new in the discourse of Tibetan Buddhism. Nor are the discussions pertaining to subjectivity and derivation of concepts from an aesthetic experience. Similarly to Kant, these discussions are contextualized by the notion of Enlightenment. Although Kant himself may not have emphasized the importance of the experience of Enlightenment in relation to his Critiques to the same literary extent to which Tibetan philosophers applied the view of Enlightenment in their literature, it is significant to draw parallels and similarities between these respective projects. Since Enlightenment is discussed as the ultimate achievement of the path, it undertakes multiple methodical forms of practice, depending on the advocacies of a sub-school. This section is devoted to the intellectual evolution of the Mādhyamika tradition in Tibet.

It is salient here to evoke Priest's conceptual/epistemic distinction. Sambhogakāya is considered a body that is beyond time and material conditionings. This type of body is a divine form of Enlightenment, which is used by the practitioner as a meditative vehicle to progress on the path (Chögyal, 1989). Therefore, it is not that these divine bodies have no conceptual content, but rather that the meditative experience of these deities are not accessed via conceptual reasoning. The functional role of ignorance is that it obscures perception towards understanding reality. The metaphor of ignorance behaving as some sort of cataract to our mundane perception is often mentioned in Tibetan teachings. The purpose of practice, including but not limited to devotion and meditation, is to remove the cataract of ignorance so that we can see reality and achieve liberation (Köngtrul, 2005).

The essential component of progressing on the path is bodhicitta (byang chub kyi sems).It is the cultivation of the mind that aspires to achieve Enlightenment for the sake of all sentient beings. One of the features of bodhicitta is an attitude that all sentient beings should reach the state of liberation (Ngari, 1996). Bodhicitta and Kant's view of purposiveness contain striking parallels. They are both described as both inside and outside causality and designation, depending upon the application of these 
notions. If bodhicitta and purposiveness are used in a context that does not necessitate causal ascription, they are somehow understood to be categorized as purely theoretical. At the same time, if there is a causal maxim ascribed to these notions, they undertake epistemic and conceptual grounding in practical reasons. Purposiveness is a scaffolding tool evoked by Kant for subjects to mediate between theoretical and practical reasons, as well as understanding some sort of relationship between feelings of duty and respect in a framework of causal maxims of universalizability.

Prāsangika Mādhyamika is a philosophical branch that discusses the dimension of two-truth doctrine (bden pa gnyis) in Buddhist philosophy. These truths are known under the designations of conventional and ultimate truth. The conventional truth addresses dimensions of the mundane experience and observable phenomena. For that reason, it is known as obscurational truth, whereas ultimate truth pertains towards reality itself, as is not a referend to awareness (Vose, 2009). The main positions I shall summarize belong to Chapa Chökyi Senge (phywa pa chos kyi seng ge), Jetsün Drakpa Gyaltsen (rje btsun grags pa rgyal mtshan) and Lama Tsongkhapa Lobzang Drakpa (tsong kha pa blo bzang grags pa). One of the primary starting points towards understanding Mādhyamika debates in Tibet between the twelfth and fifteenth centuries is the discussion around the effibility of ultimate truth. The beginning assumption of the discussion was that ultimate truth is ineffable. ${ }^{10}$ However, there were questions remaining. How do sentient beings have epistemic access into the ultimate truth? If there can somehow be a presupposition that although the instruments of language are not equipped to properly explain ultimate truth? Do our cognitive activities have some direct or indirect access into this ineffable truth?

Both Drakpa Gyaltsen and Tsongkhapa have been influenced by Chapa Chökyi Sengé (phywa pa chos kyi seng ge). Chapa developed a further dichotomization of ultimate truth, into concordant and non-concordant ultimate truths. The concordant ultimate is the limb that is epistemically and conceptually accessible to us. We use words like "ultimate truth", hence they must refer to some object or entity. Our syntax can autonomously sustain some sort of concept, however minimal in reference to an unknowable or at least indescribable ultimate, such that there can be a discourse surrounding this notion, in the realms of logic, epistemology and linguistics. The un-concordant ultimate, on the other hand, is neither assessable nor assertible in any way. ${ }^{11}$ Tsongkhapa encourages and supports this soft distinction of ultimate truth, though the emphasis remains on conceptual ascriptions. Although he credits Chapa for the development of the concordancy-based distinction of the ultimates, Tsongkhapa states that even concordancy itself has equivalent applicability to both the perceiver and the object perceived, hence we should further interpret the notion of concordancy into subjective and respectively, objective concordancy. ${ }^{12}$ In this way, the cognitive activity producing reasoning and analysis, as well as the object in reference to which the analysis is done, are equally concordant as far as our conceptual and epistemic access into the non-concordant ultimate. Therefore, only a "nonconceptual wisdom realizing emptiness comes to be called the ultimate, not the

\footnotetext{
10 Ibid. Vose pp. 87.

11 Ibid. Vose pp. 99.

12 Ibid. Vose pp. 103.
} 
concordant ultimate". ${ }^{13}$ The conditions satisfying the realization of emptiness have become an inexhaustible debate since the inception of Mādhyamika. The discussions have usually not only been primarily evoked in the context of the two truths, but also about the cognitive implications it has over practitioners and the ability to advance on the path. In contrast to Tsongkhapa, Drakpa Gyaltsen contextualizes the concordancy distinction towards the notions of Enlightened and Unenlightened perception. Gyaltsen's primary concern was towards whether Buddhas experience conventional experiences as unenlightened beings. Such commentary is present in Gyaltsen's elaboration of Chandrakīrti:

Buddha's non-conceptual minds are ultimate; [their] pure worldly wisdom (dag pa 'jig rten pa'i ye shes), being supported by [non-conceptual] wisdom, is a figurative conventional. Therefore, this is also non-abiding nirvāna. ${ }^{14}$

Gyaltsen's original move in the debate is providing the notion of concordant conventionals. Beforehand, the distinction of concordancy was only applied to ultimate truth. Since Gyaltsen emphasizes the difference in cognitive experiences between enlightened and unenlightened beings, the deferment to a further distinction of concordancy of the conventional is quite sensible. Gyaltsen's observation was that Prāsangika literature was moving into a direction in which Buddhas were denied mundane perception. Therefore, Gyaltsen arguably leans closer to the view that Buddhas can perceive both conventional appearances and ultimate reality in order to benefit all sentient beings.

To Tsongkhapa, only concordant ultimates are in the realm of linguistic and conceptual accessibility. Even with that paradigm, Tsongkhapa holds that the final ultimate is beyond conceptual access and elaboration. Vose illustrates that one of the most important distinctions between Gyaltsen and Tsongkhapa pertains to the applicability of Enlightened perception towards the nature of intervention of Buddhas into the mundane world:

Whereas Drakpa Gyaltsen faulted the Prāsanigika view for not allowing non-abiding nirvāna, the Svātantrika view of a Buddha having both non-conceptual wisdom and a pure worldly wisdom enables an explanation of non-abiding nirvāna, in which Buddhas are both fully realized and fully able to aid sentient beings. ${ }^{15}$

In the spirit of Rimé (ris med)as a movement against sectarianism and schoolfavoritism (Tulku, 2006), I am not going to particularly defend Gyaltsen or Tsongkhapa. They both made important contributions to the Tibetan debates in the medieval era. Additionally, both thinkers attribute their intellectual development to Candrakinti. Since the purpose of all Buddhist practitioners is to achieve liberation via the methods of compassionate wisdom, it is also salient to highlight the monistic undertone in these Tibetan discussions. Candrakīti himself stated in his Sevenfold Reasoning (rnam bdun gyi rigs pa) (Wilson, 2001):

\footnotetext{
13 Ibid. Vose pp. 103.

14 Ibid. Vose pp. 106.

15 Vose Ibid pp. 107.
} 
[Nāgārjuna] taught investigations in the Treatise [on the Middle Way] not out of attachment of disputation but for liberation; they are teachings of reality. ${ }^{16}$

Therefore, these sophisticated debates discussing the limits of thought, perception and analysis must remain within the broader context of altruism and liberation, rather than some mere competitiveness for the most orthodox paradigm. In a similar way in which I attempted to complement Burgess' analysis of Kantian free beauty by emphasizing the criteria of purposiveness, I would like to stress the idea that the aforementioned Tibetan debates have at their foundation understanding the teachings of the Buddha with the inherent purposiveness and attitude of compassion. Discussions pertaining to moral purposiveness in both the Kantian and Tibetan lens should be understood as necessary antecedents to notions of ineffability and analysis.

These dimensions of purposiveness, ethical conduct and the paradox of effibility are highlighted in Pakpa Drogon Chogyal's ('gro mgon chos rgyal 'phags pa) visit to Mt. Wutai. The five-peak mountain is known as the residence of Mañjuśri, the bodhisattva of wisdom (Lin, 2014). The mountain became a place of worship and pilgrimage during the Tang Dynasty. During the thirteenth century, Pakpa was one of the first Tibetans visiting the location, with an attempt of not only justifying a Chinese place of worship which had no affiliation with the originally Indian tradition of Buddhism, but also to establish a connection between the Tibetan tradition of Buddhism and the Chinese (Yi, n.d.). Pakpa went with the intention of asking Mañjuśri questions about divination and astrology, which are said to be hidden at the peak of the mountain. The bodhisattva of wisdom is an extraordinarily significant figure to Pakpa, since one of the five Sakya founders, Sakya Pandita (sa skya legs bshad), is considered to be an emanation of Mañjuśri. ${ }^{17}$

Pakpa's experience of the meditations at Wutai are quite resembling of the paradox of effibility. It is said that his pilgrimage and meditational experiences at Wutai left him with an inexpressible state. ${ }^{18}$ The metaphor encompassing Pakpa's views would be would be "like making offerings to the sea gods with water coming from the sea!". ${ }^{19}$ Eventually, Pakpa decided to display his homage via a composed piece of poetry. Kant sees poetry as the art of speech. The quality of poetic work, as Kant puts it, is that it is nondeceptive nor convoluted by rhetoric and sensible presentation (KU 5:327). ${ }^{20}$ Arguably, Pakpa provides both conceptual and epistemic closure upon Drakpa Gyaltsen's view of conventional concordancy, as well as Tsongkhapa's paradigm of conceptual access into the ultimate. By maintaining that his experience at Wutai was ineffable, there are clear signs of some sort of cognitive interaction with the world such that language cannot fully support its explanation. Lastly, Pakpa's decision to project the concordant into poetic stanzas, not only is it an attempt to reconcile the potential expressive qualities of poetic rhetoric with the ineffable, but also it should be looked at in the broader context of identifying bodhicitta as a purposiveness that is identifiable both outside a finality, as well as within it, which further disambiguates the tension in the paradox of taste, because

\footnotetext{
16 The remark by Candrakīrti can originally be traced back to his "Supplement to (Nāgārjuna's) "Treatise on the Middle Way"', Dharamsala edition, p. 178.1-.2.

17 Ibid. Yi pp. 38.

18 Ibid. Yi pp. 41.

19 Ibid. Yi pp. 41.

${ }^{20}$ Guyer and Wood Ibid pp. 205.
} 
the concepts use to express the mental state were not written for a purpose to advance a discourse, but merely to have some grounding for an explanation.

\section{Tibetan Art in the Yuan-Ming Era}

Kant's Seventh Thesis in the Idea for a Universal History from a Cosmopolitan Point of View states:

The problem of establishing a perfect civic constitution is dependent upon the problem of a lawful external relation among states and cannot be solved without a solution of the latter problem. ${ }^{21}$

The social and political dynamics regarding the development of equitable civic structures and norms are not merely limited to internal state building, but also towards the state of affairs between nations. The Tibetan and Chinese governments were quite aware and responsive towards the expansion of the Mongolian regime. The Yuan Dynasty has been the only one in China that has not been ruled by the Chinese themselves, but rather by the Mongols. In contrast, the political rule of Tibet has also experienced major changes in the twelfth century due to civil unrest and a deterioration in governmental authority, which opened the vacuum for monastic rule (Shakabpa, 2010).

The post-Genghis Khan Yuan-Tibetan relation was also established via the route of rituals and deity practices. The Mongolian leaders were initiated in Tibetan tantras. One of the earliest examples of this is found in a conversation between Pakpa and Kublai Khan. Pakpa, as per the tradition of Tibetan Buddhism, has followed to procedure to request an offering. In this case, Pakpa has asked to be included in the circle of Mongolian decision making. He has asked Kublai to obey the orders of the master, as a student listens to the instructor. ${ }^{22}$ Kublai responded with obedience. He stated that the lama shall sit in a position of honor during both religious teachings as well as political decisions. In return, Kublai Khan returned the unified kingdoms of Tibet under Sakya rule. ${ }^{23}$ The most historically recognized and recorded initiation by Pakpa to the Khan lineage is the Hevajra tantra (kye rdo rje'i rgyud, kyai rdo rje rgyud or dgyes pa) (Weirong, 2011a). As a result, Pakpa also became the first imperial preceptor of the Yuan under Kublai Khan. ${ }^{24}$ During Pakpa's supervision, two stūpas were built in Beijing (1279) and Wutai (1301), respectively. ${ }^{25}$

Although the Yuan Dynasty was primarily administered by the Mongols, they nonetheless perceived themselves as a dynastic continuation of Chinese rule (Jing, 1194). In order to further justify their authority, the Mongols also adopted the Chinese calendar to celebrate the unification of China's mainland and gain support from the Han-Chinese. The Mongols also translated the calendar into Mongolian to justify their progress domestically (Kai-Lung \& 何凱龍, 2006). Thus, the inherent civil structure supporting Chinese social order, codified under the Mandate of Heaven, became a

\footnotetext{
21 Ibid Beck pp. 420.

22 Ibid. Shakabpa p. 217.

23 Ibid. Shakabpa p. 230.

24 Ibid Weirong pp. 542.

25 Ibid. Weirong pp. 543.
} 
supplement to Mongolian leadership in the Yuan Dynasty. The ingenious Mongolian support towards Tibetan Buddhism and Pakpa, was a display of a systemic, top-down reform of China, Mongolia, as well as Tibet.

The transition to the Ming Dynasty also contains Kantian underpinnings. The Seventh Thesis continues:

All wars are therefore only so many attempts (not, to be sure, in the aims of human beings, but yet in the [8:25] aim of nature) to bring about new relationships between states, and through destruction or at least dismemberment of all of them to form new bodies, which, however, once again cannot preserve themselves either in themselves or next to one another and hence must suffer new, similar revolutions until finally, partly through the best possible arrangement of their civil constitution internally, partly through a common agreement and legislation externally, a condition is set up, which, resembling a civil commonwealth that can preserve itself like an automaton (Allison, 2009). (my italics)

Although the Ming Dynasty began with a Chinese uprising orchestrated by Zhu Yuan Zhang (Chu Yuan-chang) (Hung, 2016), Ming's social and political culture did not dispense of the Tibeto-Mongolian influence left from the Yuan Dynasty. Weirong attests that there were to scriptures discovered in the Ming Dynasty, relating to rituals of Tibetan Buddhism, one of which belonged to the Hevajra tantra (Weirong, 2011b; Himalayan Art Resources (HAR) n.d.; Watt, Jeff. Hevajra (Buddhist Deity), 2014; Watt, Jeff. Hevajra (Buddhist Deity), 2017a; Watt, Jeff. Hevajra (Buddhist Deity), 2017b; Watt, Jeff. Manjushri (Bodhisattva \& Buddhist Deity), 2011; Watt, Jeff. Refuge Field (Buddhist), 2020).

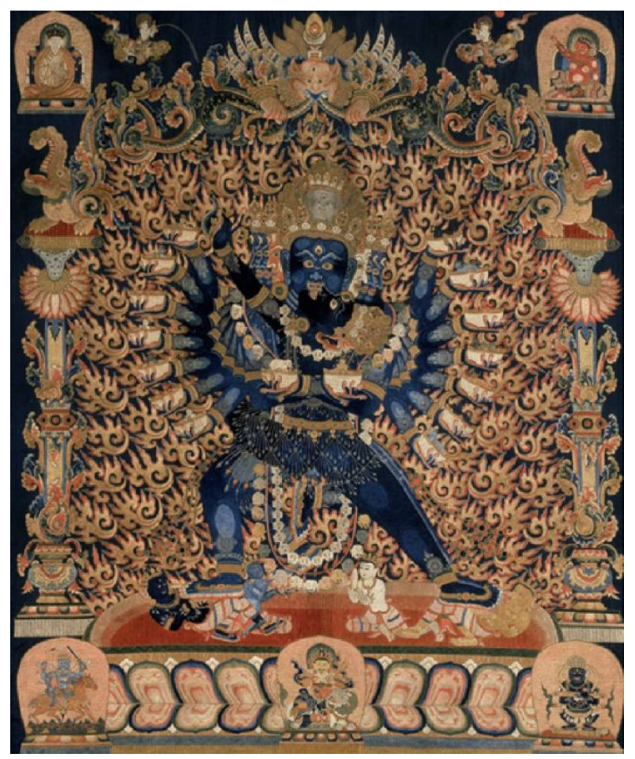

(Hevajra, $15^{\text {th }}$ Century China, Himalayan Arts Website, Entry \#58366) 
Tibetan aesthetics did not only find a continuous place within the present Buddhist traditions of China. The ritual of shuilu zhai is performed for the honoring of the untended spirits of the dead. This ritual, although initially conceived by Confucians, has eventually been appropriated by the Chinese Buddhists and Taoists. With the arrival of the Tibetan tradition, they have also incorporated Mahāmāyūrī, a deity primarily found in the Indo-Tibetan tradition (Debreczeny, 2003). The Hevajra teachings as well as Tibetan Buddhism broadly have stood the test of time in Chinese and Mongolian culture, even beyond the presence it had during the Ming era.

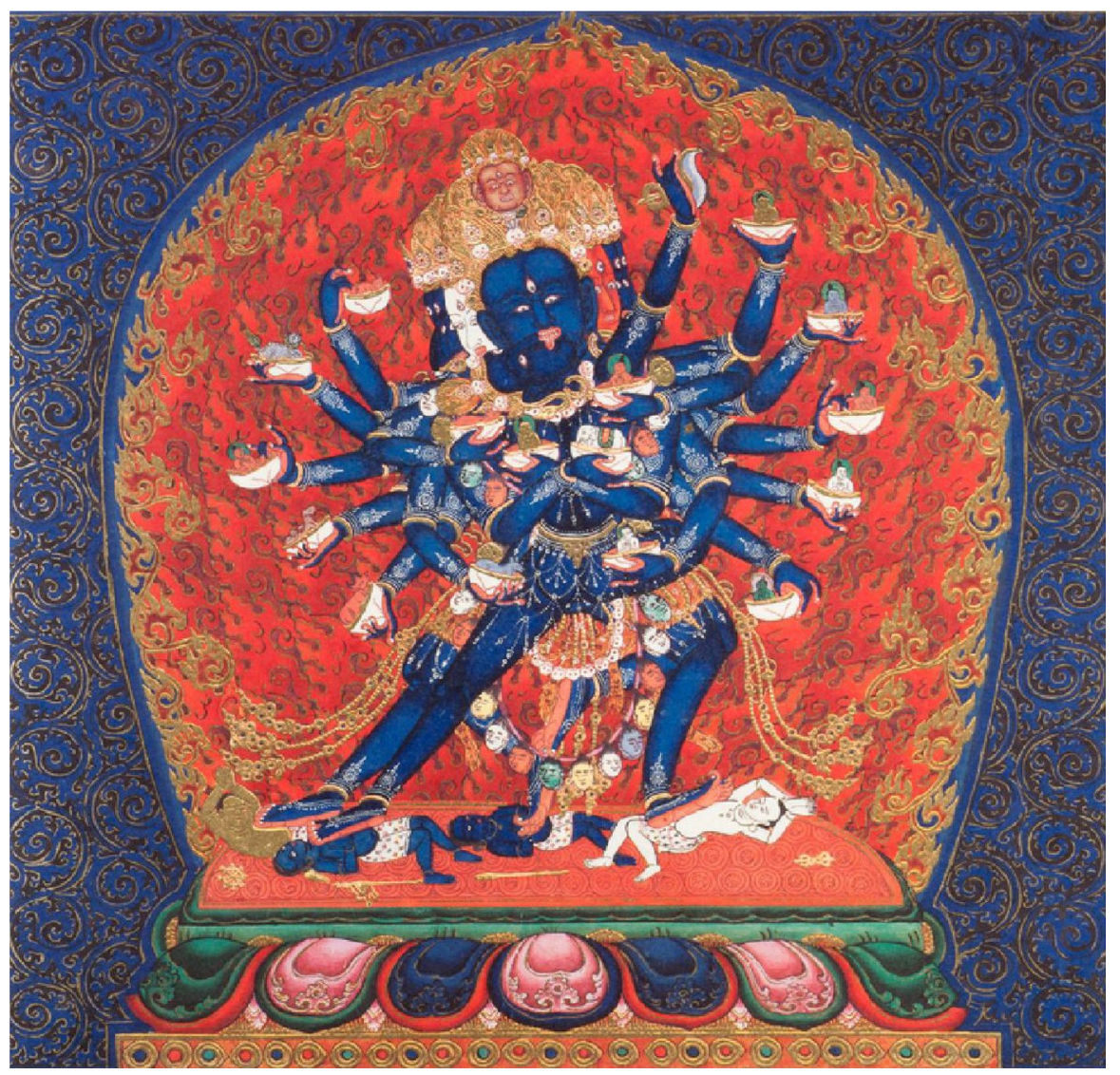

(Hevajra, $18^{\text {th }}$ Century China, Himalayan Arts Website, Entry \#20382) 


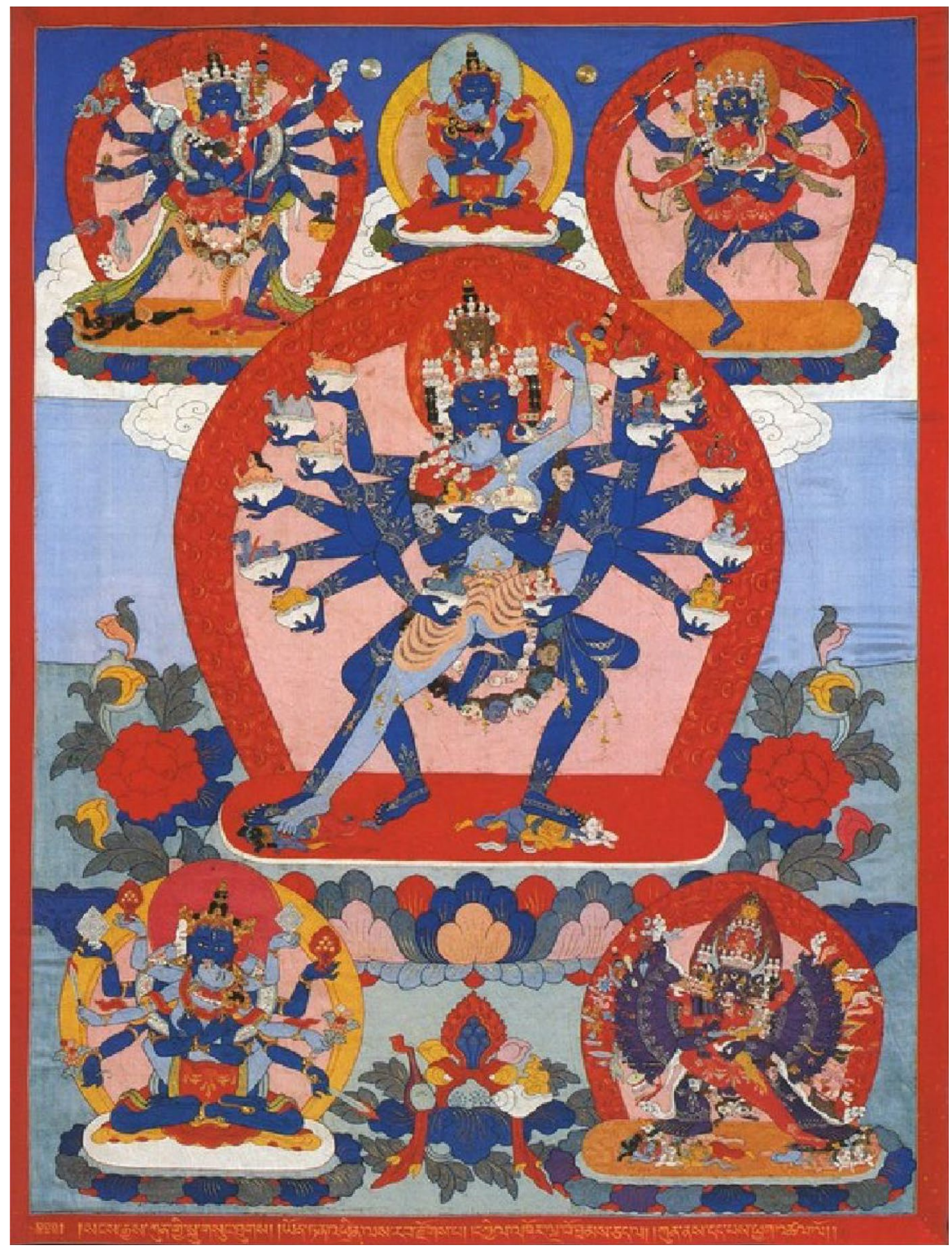

(Hevajra, $19^{\text {th }}$ Century Mongolia, Himalayan Arts Website, Entry \#49062) 


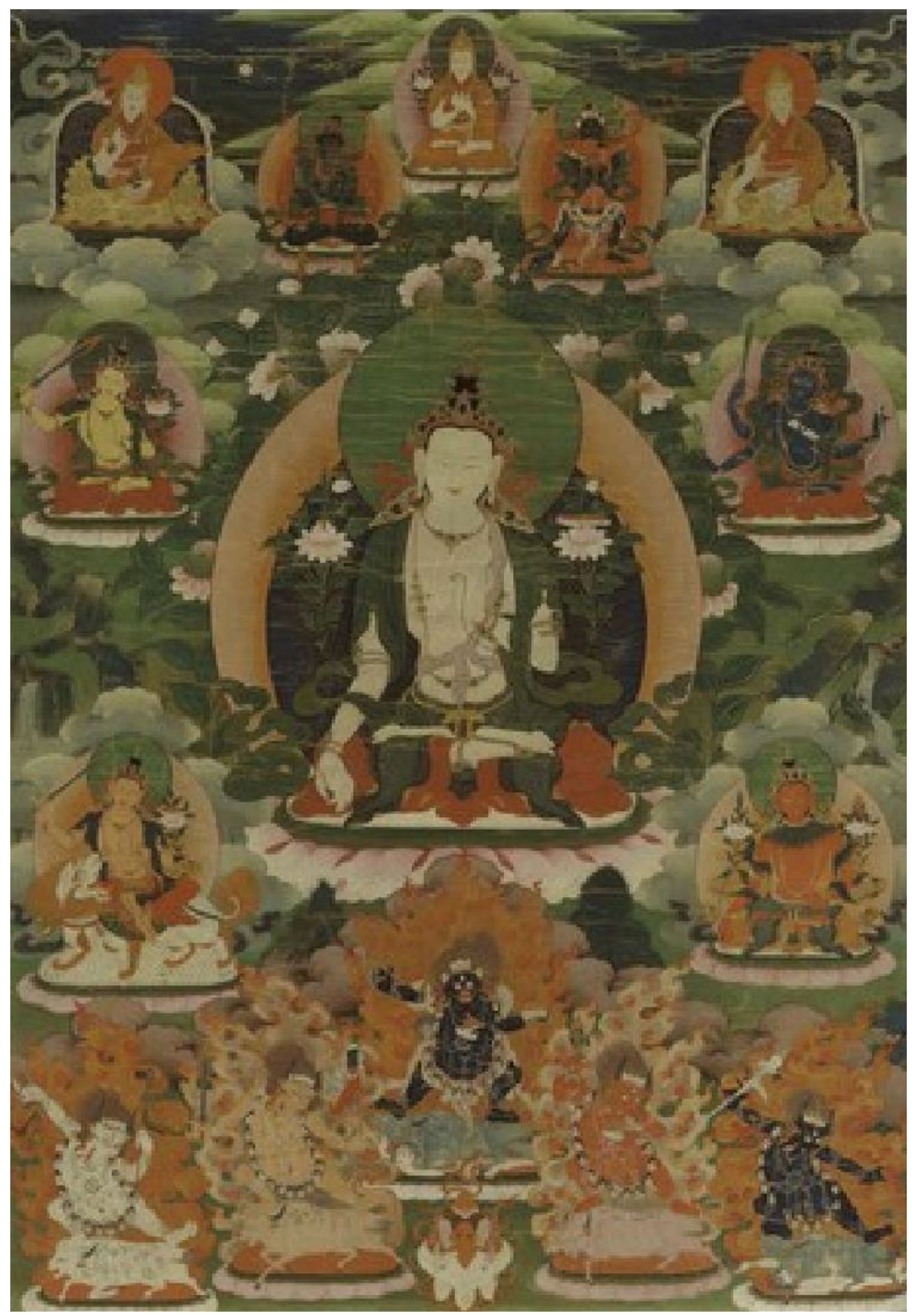

(Five forms of Mañjuśri at Mt. Wutai, $18^{\text {th }}$ century China, Himalayan Arts Website, Entry \# 88767) 


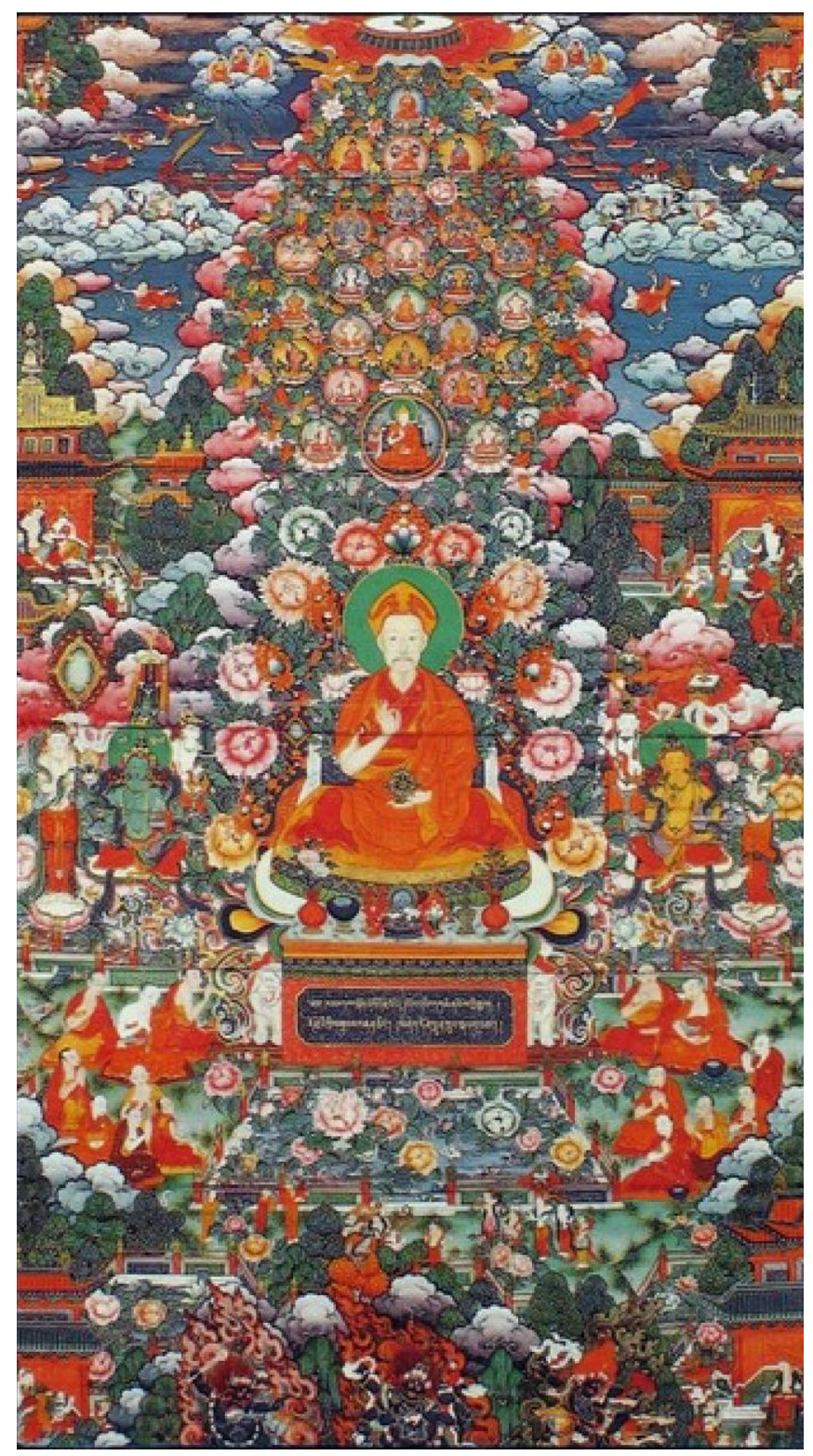

(Buddhist Refuge Tree with Qing Emperor, $19^{\text {th }}$ Century China, Himalayan Arts Website, Entry \# 99433)

The form of Mañjuśri in the center is White Mañjuśri, a Kriya Tantra initially from the The Tantra of Siddhaikavīra ( $d p a$ ' bo gcig pu grub pa'i rgyud). Although we do not have sufficient hagiographical evidence to assess at which point did this particular scripture reach China, it would be fair to assume that the dissemination occurred at 
some point after Pakpa's visits to Mt. Wutai, and that by the eighteenth century the text was fully translated into Chinese. The Refuge Tree depicting the Qing emperor could also be understood as evidence that the fundamental practice of refuge has found civic and religious convergence with Chinese leadership as well.

The broader Kantian thematic question is whether or not these systemic changes in medieval Asia have led to what he would consider an Enlightened society. The prominence and continuity of Tibetan art was a manifestation of dependent beauty. Its aesthetic experience and worth were never merely in the hands of a tradition or subject, nor determined by the intervention of governmental institutions. The deities portrayed in Thangka art have found support from Mongolian leadership, Chinese Buddhists, Confucianists, as well as their indigenous Himalayan progenitors. These forms of philosophical and artistic preservation point out to a bottom-up or rather grassroots civic movement to preserve the heritage of the teachings. Lastly, Pakpa's poetic dedications to Mañjuśri also seem to engage with the dynamic of senses as cognitive mediators from free to dependent beauty. Although initially speechless towards the awes of Wutai, he eventually decided to engage with poetry as means to express the inner experience. Drakpa Gyaltsen, a Sakya predecessor to Pakpa, has undoubtedly influenced Pakpa's philosophical views. Drakpa Gyaltsen's views of concordancy, partially imported from the Hevajra Tantra, state that mundane perception obscures ultimate truth. The purification of the obscurations leads to liberation. ${ }^{26}$

\section{Conclusion}

The linguistic and pragmatic implications for this discussion are difficult to frame from the mere parallelism to Kant. It is somewhat difficult to assess whether the portrayal of Tibetan art in conjunction with Mongolian, Tibetan and Chinese political frameworks rely upon some sort of ontological construction of these images. Clearly, the deities themselves were seen and interpreted as more than linguistic or fictive constructions of imagination. Nor is it sufficient to claim that these artistic portrayals were behaving as some sort of cognitive scaffolding for the practitioners. There is a truth within the religious and linguistic practices of these artistic depictions that gave life and purposiveness to the artistic and political activities of Medieval Asia. They were not only seen as products of imagination, but rather sacred teachings passed from the Buddha himself. Therefore, in the project of finding philosophical and historical parallels with Western conceptual frameworks, whether Kantian or not, it is important to understand the truth that these artistic depictions were projecting. Overall, Tibetan philosophy and art have contributed tremendously to the construction of Asian civilizations.

Funding Open Access funding provided by Universität Zürich.

Open Access This article is licensed under a Creative Commons Attribution 4.0 International License, which permits use, sharing, adaptation, distribution and reproduction in any medium or format, as long as you give appropriate credit to the original author(s) and the source, provide a link to the Creative

26 Ibid. Vose pp. 105. 
Commons licence, and indicate if changes were made. The images or other third party material in this article are included in the article's Creative Commons licence, unless indicated otherwise in a credit line to the material. If material is not included in the article's Creative Commons licence and your intended use is not permitted by statutory regulation or exceeds the permitted use, you will need to obtain permission directly from the copyright holder. To view a copy of this licence, visit http://creativecommons.org/ licenses/by/4.0/.

\section{References}

Allison, H. (1966). Kant's theory of taste- a reading of the critique of aesthetic judgment (p. 94). Cambridge University Press.

Allison, H. (2009). Teleology and history in Kant: The critical foundations of Kant's philosophy of history. In AmélieOksenberg. Rorty \& James Schmidt (Eds.), Kant's idea for a Universal History with a Cosmopolitan aim (p. 17). Cambridge University Press.

Beck, L. W. (1998). Kant selections (p. 391). Pretince-Hall.

Burgess, C. (1989). Kant's key to the critique of taste. The Philosophical Quarterly (1950-), 39(157), 487. Oxford University Press.

Chögyal, N. N. (1989) [chos rgyal nam mkha'i nor bu], "Dzogchen, the Self-Perfected State", Shane John translation. Snow Lion Publications

Davies, S. (2012). The artful species (p. 16). Oxford University Press

Debreczeny, Karl. (2003). Sino-Tibetan artistic synthesis in Ming Dynasty Temples at the Core and Periphery. The Tibet Journal, 28(1/2), 60. Contributions to the History of Tibetan Art.

Falkenstein, L. (2004). Kant's Intuitionism- a commentary on the transcendental aesthetic (p. 96). University of Toronto Press.

Himalayan Art Resources (HAR) (n.d.). https://www.himalayanart.org.

Hung, H. M. (2016). From the Mongols to the Ming Dynasty: How a Begging Monk became Emperor of China, Zhu Yuan Zhang (p. 24). Alogra Publishing.

Jing, A. (1194). The Portraits of Khubilai Khan and Chabi by Anige (1245-1306), a Nepali Artist at the Yuan Court. Atribus Asiae, 54(1/2), 74

Kai-Lung, H., \& 何凱龍. (2006). The political power and the Mongolian Translation of the Chinese Calendar During the Yuan Dynasty. Central Asiatic Journal, 50(1), 57.

Kant, I. (2000). In P. Guyer \& A. Wood (Eds.), Critique of the power of judgment. Cambridge University Press.

Köngtrul, J. (2005). ('jam mgon kong sprul) "Treasury of Knowledge: Systems of Buddhist Tantra”, McLeod Ingrid and Guarisco Elio translation, pp. 146, pp. 398. Snow Lion Publications.

Lin, W.-C. (2014). Building a Sacred Mountain: The Buddhist Architecture of China's Mount Wutai (p. 5). University of Washington Press.

Ngari, P. (1996). (mnga' ris pan chen padma dbang rgyal), "Perfect Conduct- Ascertaining the Three Vows" (rang bzhin rdzogs pa chen po'i lam gyi cha lag sdom pa gsum rnam par nges pa zhes bya ba'i bstan bcos), Khenpo Gyurme Samdrub and Sangye Khandro translation (pp. 9). Wisdom Publications.

Priest, G. (1995). Beyond the limits of thought (p. 89). Cambridge University Press.

Shakabpa, T. W. D. (2010) One hundred thousand moons - an advanced political history of Tibet (Vol. 1, pp. 173). Brill's Tibetan Studies Library

Tulku, R. (2006). The Ri-Me Philosophy of Jamgön Kongtrul the Great: A Study of the Buddhist Lineages of Tibet (p. xiii). New York: Shambala Publications.

Vose, K. (2009). Resurrecting Candrakīrti, disputes in the Tibetan creation of Prāsangika (p. 22). Wisdom Publications.

Watt, Jeff. Hevajra (Buddhist Deity). (2014). (Hevajra Tantra), Himalayan Arts Resources (HAR). https:// www.himalayanart.org/items/58366

Watt, Jeff. Hevajra (Buddhist Deity). (2017a). (Hevajra Tantra), Himalayan Arts Resources (HAR). https://www.himalayanart.org/items/203802

Watt, Jeff. Hevajra (Buddhist Deity). (2017b). (Hevajra Tantra), Himalayan Arts Resources (HAR). https://www.himalayanart.org/items/49062 
Watt, Jeff. Manjushri (Bodhisattva \& Buddhist Deity). (2011). (Wutaishan Mountain), Himalayan Arts Resources (HAR). https://www.himalayanart.org/items/88767

Watt, Jeff. Refuge Field (Buddhist). (2020). Gelug Lineage, Himalayan Arts Resources (HAR). https:// www.himalayanart.org/items/99433

Weirong, S. (2011a). Tibetan Buddhism in the Mongol-Yuan China (1206-1368). In O. Charles (Ed.), Esoteric Buddhism and the Tantras of East Asia (p. 542). Brill.

Weirong, S. (2011b). Tantric Buddhism in Ming China. In O. Charles (Ed.), Esoteric Buddhism and the Tantras of East Asia (p. 543). Brill.

Wilson, J. (2001). Candrakirti's sevenfold reasoning: Meditation on the selflessness of persons (p. 2). Siddhacarya Publications.

Yi, D. (n.d.). "Translating” Wutai Shan into Ri bo rtse lnga (Five-Peak Mountain)- The Inception of a Sino-Tibetan Site in the Mongol-Yuan Era (1206-1368), Journal of Tibetology (vol. 18), Edited by Center for Tibetan Studies of Sichuan University Chengdu, China, First Published in June 2018 China Tibetology Publishing House Beijing, China.

Publisher's Note Springer Nature remains neutral with regard to jurisdictional claims in published maps and institutional affiliations. 